\title{
Review
}

\section{A Possible Role for CSF Turnover and Choroid Plexus in the Pathogenesis of Late Onset Alzheimer's Disease}

\author{
Jean-Marie Serot*, Jadwiga Zmudka and Pierre Jouanny \\ Department of Geriatry, CHU Amiens, Amiens Cedex 1, France
}

Accepted 24 January 2012

\begin{abstract}
According to the amyloid theory, the appearance of amyloid- $\beta(A \beta)$ deposits represents a pivotal event in late onset Alzheimer's disease (LOAD). Physiologically, $\mathrm{A} \beta_{42}$ monomers are cleaned by capillary resorption, enzymatic catabolism, and cerebrospinal fluid (CSF) transport. Factors that promote the oligomerization of $A \beta_{42}$ must be specified. In vitro, these monomers spontaneously form neurotoxic oligomers whose rate increases with time suggesting that the stasis of CSF favors the oligomerization. In animals, experimental hydrocephalus generates CSF stasis followed by the appearance of amyloid deposits. In normal pressure hydrocephalus, amyloid deposits are common, especially in elderly patients, and the turnover decline has the same order of magnitude as in AD. In this disease, the effects of CSF stasis are potentiated by the decline in the ability of CSF to inhibit the formation of oligomers. CSF originates from choroid plexus (CP). In LOAD, the functions of secretion, synthesis, and transport of $\mathrm{CP}$ are impaired and this is related to morphological modifications. These impairments favor the decrease of CSF turnover, the diminished levels of transthyretin, a sequestering protein synthesized by $\mathrm{CP}$, and the oligomerization of $\mathrm{A} \beta_{42}$. They are potentiated by a reduced enzymatic catabolism and a decreased capillary reabsorption of $A \beta_{42}$, both alterations being related to age.
\end{abstract}

Keywords: Alzheimer's disease, cerebrospinal fluid, choroid plexus, turnover

\section{INTRODUCTION}

Alzheimer's disease (AD) is a progressive agerelated neurodegenerative disease whose incidence increases dramatically with age. From age 65 to 90 years, the annual incidence is multiplied by 20 and rises to 56 per 1000 person-years in patients older than 90 years [1]. Despite increasing knowledge and advances in treatment, this disease is always fatal within a few years.

Pathologically, AD is characterized by the coexistence of two types of lesions: amyloid plaques that consist mainly of extracellular deposits of amyloid- $\beta$

${ }^{*}$ Correspondence to: Jean-Marie Serot, Department of Geriatry, CHU Amiens, 80054 Amiens Cedex 1, France. Tel.: +33 322455710; Fax: +33 322455342; E-mail: serot.jean-marie@chu-amiens.fr.
(A $\beta)$ peptide fibrils, which have several isoforms ( $\mathrm{A} \beta_{40}, \mathrm{~A} \beta_{42}$, and $\mathrm{N}$-truncated species) and intracellular neurofibrillary degeneration consisting of twisted filaments of hyperphosphorylated tau [2]. The amyloid theory suggests that deposits of $A \beta_{42}$ are the key event of this disease and that they precede clinical signs by several years [3-5]. This peptide can be removed by capillaries, enzymatically degraded, or eventually eliminated into cerebrospinal fluid (CSF) [6].

Hereditary AD is uncommon and results from mutations of the amyloid- $\beta$ protein precursor $(\mathrm{A} \beta \mathrm{PP})$ or presenilins (PS-1 and PS-2), which cause the formation of oligomers by hyperproduction of $A \beta_{42}$, increase of its aggregatability, or decrease of its catabolism [7].

Late onset Alzheimer's disease (LOAD) represents the majority of $\mathrm{AD}$ cases. It is defined by onset at age 
65 years or older and appears to affect around $50 \%$ of all people over the age of 90 . It is often observed with a strong familial clustering [7]. The natural history of LOAD is becoming better known. Deposits of $A \beta_{42}$ oligomers begin many years before the first clinical signs [4]. They are neuro- and synapto-toxic and induce the phosphorylation of tau [8]. The rate of oligomers in brain tissue from $\mathrm{AD}$ patients is 12 times higher than that of controls [9].

LOAD is a complex multifactorial disease. Age, diabetes, hypertension, dyslipidemia, physical and cognitive inactivity, smoking, and low educational attainment are well known risk factors [10]. Several hereditary risk factors have been identified including ApoE4 gene that confers a higher risk, presumably by impaired clearance of $A \beta_{42}$ [11]. CLU, PICALM, $\mathrm{CR} 1$, and BIN1 have been recently discovered, but they exert modest effects on AD risk [7, 12]. Antiamyloid therapies are effective in transgenic mice, but to date in humans they are disappointing, probably because the etiology is more complex and that $\mathrm{A} \beta$ alone cannot explain all aspects of AD. The factors that promote oligomerization of $A \beta_{42}$ and the amyloid-independent mechanisms should be specified to prevent and treat this dreadful disease more effectively [13].

Disorders of CSF hydraulics have long been known but their place in the pathogenesis of $\mathrm{AD}$ remains elusive [14-17]. We propose to study the role of CSF, its turnover, and choroid plexus (CP), which secretes the highest amount of CSF and thus may play a key role in the pathogenesis of this disease. Here we present the various ideas supporting our hypothesis.

\section{A $\boldsymbol{\beta}_{42}$ METABOLISM}

$A \beta_{40}$ and $A \beta_{42}$ are physiological catabolytes of a membrane precursor A $\beta P P$, expressed in many tissues and particularly by astrocytes, neurons, and platelets. These monomers are not neurotoxic and are found in plasma, CSF, and interstitial fluid (ISF). In vitro, placed in saline, they spontaneously form soluble oligomers of 3-50 A $\beta$ monomers, then soluble protofibrils, and finally fibrils whose rate increases with time; $A \beta_{42}$ oligomerizes more rapidly than $A \beta_{40}[18,19]$.

A significant proportion of $A \beta_{42}$ comes from outside the brain, mainly from the platelets. The brain capillaries can reabsorb plasma $\mathrm{A} \beta_{42}$ through RAGE (receptor for advanced glycation end products) [20]. $A \beta_{42}$ is eliminated in several ways [6]. It can be reabsorbed in capillaries by two transporters, P-gp (P-glycoprotein) and LRP-1 (low density lipoprotein receptor-related protein-1), located on the luminal and abluminal side of the cerebral endothelium [21]. It can be locally degraded by several enzymes: neprilysin, insulin degrading enzyme, angiotensin converting enzyme, endothelin converting enzymes 1 and 2, and matrix metalloproteinases 2,3 , and 9 . It can be also drained into the CSF where it forms complexes with apolipoprotein $\mathrm{J}, \alpha 2$-macroglobulin, or transthyretin (TTR), that bind at a choroid carrier, megalin or LRP-2, and are sent out in the blood [22]. This way eliminates $10-15 \%$ of $A \beta_{42}$ and seems secondary [6].

During physiological aging, neprilysin activity rates decrease [23]. In capillaries, the levels of LRP-1 decrease and the rates of P-gp decrease significantly only in very old animals (30-36 months) [20]; the expression of RAGE decreases until 9 months and then progressively increases [24]. In CPs, the modifications are different; the RAGE expression does not vary, there is an increase in the transcription of the $\mathrm{A} \beta$ efflux transporters (LRP-1, P-gp), and a decrease in megalin. These opposite changes suggest a compensatory role for CPs in A $\beta$ clearance in aging. All these age-related changes should alter the clearance of $A \beta_{42}$ and probably modify the relative importance of each pathway $[25,26]$. However, these defects are not enough to induce AD, since nearly $60-80 \%$ of elderly healthy controls have no overload of $A \beta_{42}$ [27].

In $\mathrm{AD}$ cases, there is a strong positive microvascular RAGE immunoreactivity, suggesting that a portion of $A \beta_{42}$ is coming from outside the brain [28]. Using metabolic labeling, Mawuenyega and colleagues have measured $A \beta_{42}$ and $A \beta_{40}$ production and clearance rates in the brain of $\mathrm{AD}$ patients and cognitively normal controls. Amyloid deposits are not primarily due to an overproduction of $A \beta_{42}$ or $A \beta_{40}$ but rather to a decrease of about $30 \%$ of the clearance [29]. In AD, the activities of catabolytic enzymes of $\mathrm{A} \beta_{42}$ are modified, but some changes seem to be in reaction to the accumulation of $A \beta_{42}$ or to compensate for the declining activity of other enzymes. For example, the decrease in insulin degrading enzyme and neprilysin activities might be a late-stage phenomenon secondary to neurodegeneration [30].

\section{CHOROID PLEXUS}

CPs are small intra-ventricular organs, which form an interface between blood and CSF. By their location, we can distinguish two ventricular CPs located in each lateral ventricle, one median $\mathrm{CP}$ located in the roof 
of third ventricle, and two CPs lying in fourth ventricle. All CPs weigh approximately $3 \mathrm{~g}$ in humans and contain about $100.10^{6}$ cells [31].

They are composed of villi, with a central vascular axis, covered by a cuboidal epithelium, unistratified, ciliated, with a brush border and numerous mitochondria. The epithelial cells are separated from central vessels by a thin and regular basement membrane about $80 \mathrm{~nm}$ thick and a thin connective stroma. The height of epithelial cells is about $15 \mu \mathrm{m}[31,32]$. The capillaries are large and the endothelium is fenestrated type with pores of $30-50 \mathrm{~nm}$, and it is based on a thin and regular endothelial basement membrane about 60-70 nm thick [32]. There are also some dendritic cells lying within the epithelium and the stroma that suggest CPs may actively participate in immunological brain protection [33].

CPs are vascularized by anterior choroidal artery, terminal branch of internal carotid artery, and posterior choroidal artery, a branch of posterior cerebral artery, which itself comes from basilar artery. These arteries are widely anastomosed [34]. The blood flow of CPs was measured using radioactive microspheres and found to be approximately 4 to 7 times greater than blood flow in the cerebrum of monkeys and dogs [35].

The secretion of CSF is one of the first known functions of CPs. The movement of water is a classic osmotic movement ranging from capillaries to ventricles. As in the kidney, it is regulated by two enzymes: $\mathrm{Na}^{+} \mathrm{K}^{+}$ATPase and carbonic anhydrase [36]. Water molecules are driven by ionic gradient through water channels AQP1 located at the apical zone of cells [37].

$\mathrm{CP}$ epithelial cells have an intense enzyme activity, estimated at half that of kidney [38]. They synthesize and secrete many molecules with quantitative and qualitative variations depending on species, age, and circumstances [39]. The most abundant protein synthesized is TTR, which, in vitro, is about $20 \%$ of newly synthesized molecules and $50 \%$ of the molecules secreted by the CP epithelial cells [40].

They are the pathway to the brain for many products. Over forty carriers have been described for different types of molecules. To reach brain, folate, glucose, amino-acids, vitamins (B6, B12, C, and probably E) are actively transported by CPs [41, 42]. They actively reject brain-born compounds and, accordingly, present important neuroprotective functions. For example, they eliminate $A \beta$ from CSF by a saturable mechanism $[43,44]$, synthesize megalin, which transports $A \beta$ and several proteins (TTR, apolipoprotein J, etc.) [22], and secrete nutritive polypeptides and participate in repair processes following brain trauma [45].

With aging, CPs are the site of morphological changes. In rats, the height of epithelial cells decreases by $20 \%$ and the epithelial basement membrane thickens as the stroma [46]. In humans, epithelial cells contain Biondi bodies (ring-like structures located in the cytoplasm of choroid plexus epithelial cells) and lipofucsin deposits [47, 48]. The height of cells decreases by $10 \%$, while the thickness of the epithelial basement membrane doubles. The fibrous stroma thickens and contains psammoma bodies (round lamellar collections of calcium) and calcifications [32, 48]. The rate of calcifications increases significantly with age; by the eighth decennia, $86 \%$ of patients have $\mathrm{CP}$ calcifications [49]. The walls of arteries thicken mainly in the media, and the elastic fibers are fragmented [31, 48].

In old rats, choroidal enzymatic activities, including the rates of enzymes involved in the secretion of CSF, decrease [50, 51]. In situ hybridization analyses showed that mRNA levels for $\mathrm{Na}^{+} \mathrm{K}^{+}$ATPase and aquaporin 1 were significantly lowered in $\mathrm{CP}$ of old rats [52], and the expression of megalin (LRP-2) decreases [25]. Epithelial cells secrete less VEGF and neuroprotective properties are diminished [53].

These anatomical and enzymatic changes explain the decrease of CSF secretion. In animals, it decreases by half as well in rats than in sheep. In humans, it also declines with age. In a newborn, it is $0.60 \mathrm{ml} / \mathrm{min}$, in adult $0.41 \mathrm{ml} / \mathrm{min}$, and in elderly $0.19 \mathrm{ml} / \mathrm{min}$ [54-56].

\section{CEREBROSPINAL FLUID}

Classically about two-thirds of CSF comes from CPs and the rest comes from ISF drainage [57]. ISF is a product of the metabolism of brain cells and brain capillary endothelium. The total volume of ISF is $15-18 \%$ of the brain weight [58]. The secretion rates of ISF and CSF in the rat have been respectively estimated at $0.2 \mu \mathrm{l} / \mathrm{min}$ and $3.4 \mu \mathrm{l} / \mathrm{min}$ [58]. The evolution of ISF flow in aging is unknown.

Once secreted, CSF moves through the Sylvius aqueduct, the fourth ventricle, the Magendie foramen, and the subarachnoid spaces surrounding brainstem. CSF flow is partially generated by the systolic pulse wave [57]. Some flow continues to the spinal cord, but most of the CSF is reabsorbed in the superior longitudinal sinus and the cribriform plate of ethmoid [57]. The resistance to CSF outflow increases significantly 
with aging; this is related to fibrosis of meninges and decreased reabsorption [59].

The total volume of CSF doubles with aging according to brain atrophy. In young adults, it is about $140 \mathrm{ml}$ and more than $300 \mathrm{ml}$ in elderly [60]. The volume of ISF is approximately $280 \mathrm{ml}$ [61]. The increased volume of CSF and decreased secretion by CPs explain the decrease in turnover with age. This latter is defined by the volume of CSF produced in 24 hours divided by the volume of the CSF space. In rats, it is divided by $3[54,55]$. In humans, in newborns, young adults, and elderly controls, it is $6,4.5$, and 3 times a day, respectively [56].

CSF is not a simple ultra filtrate; its composition is different from that of plasma [41]. The level of $\mathrm{Na}^{+}$, $\mathrm{K}^{+}, \mathrm{Ca}^{++}$, and $\mathrm{HCO}_{3}{ }^{-}$are lower than in plasma. The concentration of glucose is equal to $60 \%$ of that of plasma. Folate and ascorbate levels are 3 and 4 times higher, respectively, in CSF than in plasma indicating an active transport [42]. The rate of proteins is low, less than $0.5 \mathrm{~g} / \mathrm{l}$. It varies by location: it is lower in ventricular than in lumbar [61]. The case of TTR is particular as it is synthesized exclusively by the liver and the CPs. Serum levels are 18 times higher than those in CSF, with a small quantity coming from plasma by transudation, about $3 \%$ in the ventricular CSF and $10 \%$ in the lumbar CSF. Ventricular rates are slightly lower than lumbar [40]. The rate of different proteins varies according to age. It is lower in young than in elderly patients, and this increase is inversely proportional to the decrease in the age-related CSF turnover [62]. TTR levels gradually increase with age [63].

Ependymal cells lining the ventricular cavities are not connected by tight junctions, which allows permanent exchanges. In animals, the levels of $A \beta_{40}$ and $A \beta_{42}$, measured by microdialysis in CSF and ISF, are almost similar [64]. In physiological conditions, CSF is an accessory pathway of elimination of $A \beta_{42}$ [6]. The rate of intra-ventricular $A \beta_{42}$ in healthy controls is unknown for ethical reasons. Patients with chronic communicating hydrocephalus have almost similar rates of ventricular and lumbar $\mathrm{A} \beta_{42}$ [65].

One team of scientists challenges the classical theory. Oreskovic and Klarica minimize the importance of CP secretion [66]. They are amazed to note that hydrocephalus can occur in a fully open and passable CSF system without impaired CSF circulation and absorption, and despite the established blockade of CSF pathways, the development of hydrocephalus was not always obtained. They claim that the permeability of CNS microvessels to water is relatively high and the huge area of CNS capillaries is 5000 times larger than that of CP capillaries, so the role of CNS capillaries in the filtration and reabsorption of CSF should be more important than that of CPs. They are surprised that these small organs, weighing $3 \mathrm{~g}$, secrete $300 \mathrm{ml}$ of CSF per day and question the validity of data on the CSF secretion by CPs.

All this is a matter of debate: it should be remembered that the $\mathrm{CP}$ secretion is an active process, regulated by two enzymes [36] and that some hydrocephalus are not likely due to a disorder of the CSF hydraulics. This requires further investigation. In any case, there is a continuous mixing between ISF and CSF by systolic pressure waves of blood circulation, which creates a functional unit and disperses components. The fact that AQP1 null mice had reduced CSF production and a diminished intracranial pressure reinforces the classical theory $[67,68]$.

\section{CHOROID PLEXUS, CEREBROSPINAL FLUID, AND ALZHEIMER'S DISEASE}

\section{$C S F$, an indicator of brain injury}

In LOAD, CSF analysis reveals decreased levels of $\mathrm{A} \beta_{42}$ and increased levels of t-tau (total tau) and p-tau (hyperphosphorylated tau). The increase of t-tau and p-tau reflects neuronal damage [4]. Autopsy studies have shown that the decrease of CSF-A $\beta_{42}$ is inversely proportional to amyloid load which was confirmed by using PIB PET imaging [69, 70].

Biomarker abnormalities precede clinical symptoms [4]. The finding of low CSF A $\beta_{42}$ levels associated with high p-tau rates predicts the presence of AD pathologic features with high accuracy [71]. In patients with amnesic mild cognitive impairment, this association predicts a future cognitive decline and those who rapidly decline have lower levels of $A \beta_{42}$ and higher levels of t-tau and p-tau [72]. In healthy older adults, this association correlates with a future cognitive decline [73].

CSF levels of glutamate, an important neurotransmitter toxic at high doses, are increased in patients with AD [74]. Amadori products and advanced glycation endproducts increase in the CSF of patients with AD $[75,76]$. The CSF levels of isoprostane, a non-specific marker of lipid membrane peroxidation, increase with the progression of cognitive decline, while the levels of neurofilaments light chains, which reflect the degree of neuronal degeneration and axonal loss, decrease over time [77]. 


\section{$C S F$, an agent of $A D$}

Patients with AD have significant problems of CSF hydraulics. Before the advent of computed tomography, scinticysternography was a valuable aid in the diagnosis of normal pressure hydrocephalus (NPH). After lumbar injection of a radionuclide in patients with $\mathrm{AD}$, several authors have found an intraventricular reversal flow and delayed clearance [14-17]. This could suggest a decreased secretion of CSF by CPs, and actually this secretion, measured by the method of Massermann, is divided by 2 compared to age-matched controls. In AD the CSF-turnover decreases and is less than 1.5 time a day; it might even be around 0.75 time a day [59, 78]. Furthermore a substantial proportion of AD patients have very low CSF pressure [79].

The subarachnoid injection of kaolin in rats generates hydrocephalus by altering CSF reabsorption, the resulting CSF stasis being followed by the appearance of amyloid deposits and an increase in p-tau and dendritic impairment. This accumulation appears only when the kaolin injection is applied in aged rats (12 months) and not in neonatal or young rats (3 months). This fact suggests a change in the process of clearance with age [26].

There are several human diseases in which the turnover is decreased. Particularly in idiopathic NPH, the turnover is lowered to 1.5 times a day as in $\mathrm{AD}$ [59]. Phase magnetic resonance imaging enables the quantification of CSF flow and may be of value for differentiating NPH from AD. Although these two diseases are characterized by a lowered turnover, ventricular and aqueductal CSF oscillations are much higher in NPH than in AD and healthy controls, and this hyperdynamic aspect suggests different mechanisms in CSF hydraulic disturbance [80].

Lesions of AD are common in NPH [81-86]. However, amyloid deposits are not specific for idiopathic $\mathrm{NPH}$ and are also found in secondary NPH. In a series of 433 patients with idiopathic or secondary $\mathrm{NPH}$, Leinonen and collaborators found such amyloid deposits in 186 patients (43\%) on brain biopsies [86].

Biologically, this condition is characterized by lower rates of $A \beta_{42}$, and higher t-tau in CSF $[87,88]$. The decrease of $A \beta_{42}$ levels reflects the brain sequestration [69]. Ventricular levels of $A \beta_{42}$ are lowered in idiopathic or secondary NPH, surgical hydrocephalus communicating or not communicating. In these pathologies, $A \beta_{42}$ decrease is not specific for idiopathic NPH and seems rather related to decreased turnover [65]. In patients with NPH, AD lesions increase with aging: Bech found $\mathrm{AD}$ lesions in $22 \%$ of patients with an average age 64 years, Savolainen in $31 \%$ of patients with an average age of 66 years, and Golomb in $41 \%$ of more older patients $(\mathrm{m}=77$ years) [84-86]. Silverberg found AD lesions in $75 \%$ of very old patients with idiopathic NPH [59].

All those studies show that the CSF stasis, as well in humans as in animals, promotes amyloid deposits mainly in aging. This confirms indirectly the important compensatory role of CSF and CPs in $\mathrm{A} \beta_{42}$ clearance when the abilities of enzymatic catabolism or capillary clearance are reduced $[25,26]$. In contrast, increased CSF turnover could have protective effects against amyloid deposits [89]. The long term consumption of caffeine increases $\mathrm{Na}^{+} \mathrm{K}^{+}$ATPase and CSF production in Sprague-Dawley rats [90]. In transgenic mice, longterm administration of caffeine reduces $A \beta$ deposits probably by the decreased expression of presenilin 1 and $\beta$-secretase, but the effects on CSF secretion are unknown and needed to be investigated by further studies [91].

In patients with $\mathrm{AD}$, the turnover decline has the same order of magnitude as in idiopathic NPH, but the effects of CSF stasis are potentiated by the decline in the ability of CSF to inhibit the formation of oligomers [18]. Indeed, in vitro, $A \beta_{42}$ monomers placed in saline form spontaneously oligomers within a few hours. This oligomerization is greatly reduced when the saline is replaced by CSF of control subjects; however, it decreases very little when it is replaced with the CSF of patients with AD. The CSF of healthy controls seems to contain some elements that inhibit the formation of oligomers $[18,92]$ and effectively the rates of $\mathrm{A} \beta_{42}$ binding proteins are reduced in the CSF from $\mathrm{AD}$, especially the CSF levels of cystatin $\mathrm{C}$, betatrace, and TTR, three molecules synthesized by CPs $[63,93]$.

The CSF levels of vitamin E decrease [94]. The reduced $\mathrm{CSF} /$ plasma ascorbic acid ratio predicts a cognitive decline [95]. These vitamins are carried by CPs and are two major CSF scavengers of free radicals. These decreases could explain reduced antioxidant properties of CSF [94]. The CSF levels of folate and vitamin B12, two vitamins carried by CPs, decrease significantly [96, 97]. These vitamins are involved in many brain metabolisms and particularly in methylation processes. Folate depletion could explain the increase of brain homocysteine levels and secondarily the production of highly toxic 4-hydroxy2-nonenal [98]. In vitro, folate deficiency induces an increase in p-tau immunoreactivity [99]. The decrease in turnover increases the contact time between proteins and glucose which promotes the glycation of 
proteins, including TTR, and increases oxidative stress $[75,100]$.

\section{CPs and AD patients}

In LOAD, CP changes are known since 1976 [101]. The CP morphological changes related to aging are significantly accentuated: epithelial atrophy is more important, epithelial cells lose $30 \%$ of their height, and the thickening of the epithelial basement membrane is increased. The fibrosis of stroma can reach several tenths of microns and is almost always accompanied by calcifications, mainly at glomus $[32,101]$. The percentage of cells containing Biondi bodies increases [102].

Immunofluorescence studies also show that megalin synthesis is reduced and there is an intracellular accumulation of $A \beta$ which could disturb megalin-mediated transport and protein synthesis [22]. An increase of oxidation markers has been demonstrated in Western blots performed on $\mathrm{CP}$ homogenates of patients with advanced $\mathrm{AD}$, indicating an oxidative damage related to AD progression [103]. It should be noted that CSF TTR levels are not reduced in patients with Down syndrome, a disease characterized by amyloid deposits secondary to hyperproduction of $A \beta_{42}$; this confirms that $A \beta$ deposits are not responsible for the declining of TTR rates [104].

These anatomical changes have been described in patients who died after a long development of LOAD; they could be the consequence of this disease and late onset. In fact, there are many direct and indirect arguments for a primary involvement. Experimentally the $\mathrm{CP}$ features due to a mechanical obstruction of CSF flow are different. CPs from hydrocephalic dogs, examined one month post kaolin injection, show a flattened epithelium without stroma fibrosis or thickened basement membranes [105, 106]. In humans, the disturbances of CSF hydraulic visualized by scinticisternography, the decrease of turnover and pressure of CSF have been described in patients with mild dementia [14-16, 59]. The CSF levels of TTR and cystatin $\mathrm{C}$, two molecules synthesized and secreted by CPs, and CSF vitamin B12 and folate levels, two molecules transported by $\mathrm{CPs}$, are reduced at initial diagnosis of $\mathrm{AD}[63,93,96,97,104]$. This suggests an alteration of the $\mathrm{CP}$ functions of synthesis, secretion, and transport for many years before death. These abnormalities, potentiated by reduced enzymatic catabolism and capillary clearance of $A \beta_{42}$ related to age, and, risk factors that decrease the $A \beta_{42}$ catabolism, such as the ApoE4 gene, promote a favorable environment for $\mathrm{A} \beta_{42}$ oligomerization.
Theoretically, it is logical to suspect a modification of the genes involved in the secretion of CSF [107]. It is interesting to know that a transgenic $\mathrm{CP}$ hypofunction promotes amyloid deposits: AßPPswe+/+ transgenic mice harboring a hemizygous deletion of TTR have $\mathrm{A} \beta$ deposits earlier and larger than $\mathrm{A} \beta \mathrm{PPswe}+/+$ mice without deletion of TTR [108]. In fact, up to now, genome-wide association studies have not shown genetic risk factors among these genes [12, 109]. As in kidney, the anatomical changes (fibrosis and calcifications of stroma, thickened basement membranes) suggest the involvement of environmental factors such as vascular risk factors (diabetes, hypertension, dyslipidemia).

\section{CONCLUSION}

$\mathrm{A} \beta_{42}$ is physiologically eliminated by three ways: enzymatic degradation, capillary reabsorption, and drainage into CSF where it is reabsorbed by CPs. During aging, these three ways are affected but this is not enough to cause amyloid deposits in the majority of cases.

In vitro $\mathrm{A} \beta_{42}$ monomers form spontaneously neurotoxic oligomers within a few hours, and in experimental conditions the decreased turnover of CSF by stasis favors the occurrence of amyloid deposits.

In some human diseases characterized by CSF decreased turnover amyloid deposits are common, especially in the elderly. In surgical hydrocephalus, this decline in turnover is due to a disturbance of the hydraulic and/or reabsorption of CSF, and in the case of $\mathrm{AD}$ that suggests an impairment of secretion by CPs.

In $\mathrm{AD}, \mathrm{CP}$ modifications are numerous: epithelial atrophy, fibrosis and calcifications of stroma, and thickened basement membrane. These abnormalities modify CP functions: synthesis, secretion, cleaning, and transport. The changes in $\mathrm{CP}$ result in lower turnover and CSF stasis, reduced levels of TTR and megalin; they induce altered $A \beta$ clearance, increase CSF protein glycation, oxidative stress, ascorbate and folate deficiency, and tau phosphorylation. All these arguments suggest that LOAD may be due to a decreased CSF turnover related to a choroid plexopathy.

\section{ACKNOWLEDGMENTS}

The authors thank Professor Albert Fournier for his advice.

Authors' disclosures available online (http://www.jalz.com/disclosures/view.php?id=1152). 


\section{REFERENCES}

[1] Kukull WA, Higdon R, Bowen JD, McCormick WC, Teri L, Schellenberg GD, van Belle G, Jolley L, Larson EB (2002) Dementia and Alzheimer disease incidence: A prospective cohort study. Arch Neurol 59, 1737-1746.

[2] Duyckaerts C, Delatour B, Potier MC (2009) Classification and basic pathology of Alzheimer disease. Acta Neuropathol 118, 5-36.

[3] Hardy J, Selkoe DJ (2002) The amyloid hypothesis of Alzheimer's disease: Progress and problems on the road to therapeutics. Science 297, 353-356.

[4] Jack CR Jr, Knopman DS, Jagust WJ, Shaw LM, Aisen PS, Weiner MW, Petersen RC, Trojanowski JQ (2010) Hypothetical model of dynamic biomarkers of the Alzheimer's pathological cascade. Lancet Neurol 9, 119-128.

[5] Selkoe DJ (2011) Resolving controversies on the path to Alzheimer's therapeutics. Nat Med 17, 1060-1065.

[6] Tanzi RE, Moir RD, Wagner SL (2004) Clearance of Alzheimer's Abeta peptide: The many roads to perdition. Neuron 43, 605-608.

[7] Bertram L, Lill CM, Tanzi RE (2010) The genetics of Alzheimer disease: Back to the future. Neuron 68, 270-281.

[8] Sepulveda FJ, Parodi J, Peoples RW, Opazo C, Aguayo LG (2010) Synaptotoxicity of Alzheimer beta amyloid can be explained by its membrane perforating property. PLoS One 5, e11820.9.

[9] Kuo YM, Emmerling MR, Vigo-Pelfrey C, Kasunic TC, Kirkpatrick JB, Murdoch GH, Ball MJ, Roher AE (1996) Water-soluble Abeta (N-40, N-42) oligomers in normal and Alzheimer disease brains. J Biol Chem 271, 4077-4081.

[10] Barnes DE, Yaffe K (2011) The projected effect of risk factor reduction on Alzheimer's disease prevalence. Lancet Neurol 10, 819-828.

[11] Castellano JM, Kim J, Stewart FR, Jiang H, Demattos RB, Patterson BW, Fagan AM, Morris JC, Mawuenyega KG, Cruchaga C, Goate AM, Bales KR, Paul SM, Bateman RJ, Holtzman DM (2011) Human apoE isoforms differentially regulate brain amyloid-beta peptide clearance. Sci Transl Med 3, 89ra57.

[12] Lambert JC, Amouyel P (2011) Genetics of Alzheimer's disease: New evidences for an old hypothesis? Curr Opin Genet Dev 21, 295-301.

[13] Pimplikar SW, Nixon RA, Robakis NK, Shen J, Tsai LH (2010) Amyloid-independent mechanisms in Alzheimer's disease pathogenesis. J Neurosci 30, 14946-14954.

[14] Sohn RS, Siegel BA, Gado M, Torack RM (1973) Alzheimer's disease with abnormal cerebrospinal fluid flow. Neurology 23, 1058-1065.

[15] Coblentz JM, Mattis S, Zingesser LH, Kasoff SS, Wiśniewski HM, Katzman R (1973) Presenile dementia. Clinical aspects and evaluation of cerebrospinal fluid dynamics. Arch Neurol 29, 299-308.

[16] Brusa G, Claudiani F, Piccardo A, Pizio N, Stoehr R (1990) Scinticisternography in presenile and senile degenerative disease. Ital J Neurol Sci 11, 43-47.

[17] Rubenstein E (1998) Relationship of senescence of cerebrospinal fluid circulatory system to dementias of the aged. Lancet 351, 283-285.

[18] Ono K, Noguchi M, Matsumoto Y, Yanase D, Iwasa K, Naiki H, Yamada M (2005) Cerebrospinal fluid of Alzheimer patients promotes beta-amyloid fibril formation in vitro. Neurobiol Dis 20, 233-240.

[19] Finder VH, Glockshuber R (2007) Amyloid-beta aggregation. Neurodegener Dis 4, 13-27.
[20] Silverberg GD, Messier AA, Miller MC, Machan JT, Majmudar SS, Stopa EG, Donahue JE, Johanson CE (2010) Amyloid efflux transporter expression at the blood-brain barrier declines in normal aging. J Neuropathol Exp Neurol 69, 1034-1043.

[21] Deane R, Bell RD, Sagare A, Zlokovic BV (2009) Clearance of amyloid-beta peptide across the blood-brain barrier: Implication for therapies in Alzheimer's disease. CNS Neurol Disord Drug Targets 8, 16-30.

[22] Alvira-Botero X, Carro EM (2010) Clearance of amyloid- $\beta$ peptide across the choroid plexus in Alzheimer's disease. Curr Aging Sci 3, 219-229.

[23] Hellström-Lindahl E, Ravid R, Nordberg A (2008) Agedependent decline of neprilysin in Alzheimer's disease and normal brain: Inverse correlation with Abeta levels. Neurobiol Aging 29, 210-221.

[24] Silverberg GD, Miller MC, Messier AA, Majmudar S, Machan JT, Donahue JE, Stopa EG, Johanson CE (2010) Amyloid deposition and influx transporter expression at the blood-brain barrier increase in normal aging. J Neuropathol Exp Neurol 69, 98-108.

[25] Pascale CL, Miller MC, Chiu C, Boylan M, Caralopoulos IN, Gonzalez L, Johanson CE, Silverberg GD (2011) Amyloid-beta transporter expression at the blood-CSF barrier is age-dependent. Fluids Barriers CNS 8, 21 .

[26] Silverberg GD, Miller MC, Machan JT, Johanson CE, Caralopoulos IN, Pascale CL, Heile A, Klinge PM (2010) Amyloid and tau accumulate in the brains of aged hydrocephalic rats. Brain Res 1317, 286-296.

[27] Aizenstein HJ, Nebes RD, Saxton JA, Price JC, Mathis CA, Tsopelas ND, Ziolko SK, James JA, Snitz BE, Houck PR, Bi W, Cohen AD, Lopresti BJ, DeKosky ST, Halligan EM, Klunk WE (2008) Frequent amyloid deposition without significant cognitive impairment among the elderly. Arch Neurol 65, 1509-1517.

[28] Donahue JE, Flaherty SL, Johanson CE Duncan JA 3rd, Silverberg GD, Miller MC, Tavares R, Yang W, Wu Q, Sabo E, Hovanesian V, Stopa EG (2006) RAGE, LRP-1, and amyloid-beta protein in Alzheimer's disease. Acta Neuropathol 112, 405-415.

[29] Mawuenyega KG, Sigurdson W, Ovod V, Munsell L, Kasten T, Morris JC, Yarasheski KE, Bateman RJ (2010) Decreased clearance of CNS beta-amyloid in Alzheimer's disease. Science 330, 1774.

[30] Miners JS, Baig S, Tayler H, Kehoe PG, Love S (2009) Neprilysin and insulin-degrading enzyme levels are increased in Alzheimer disease in relation to disease severity. J Neuropathol Exp Neurol 68, 902-914.

[31] Dohrmann GJ (1970) The choroid plexus: A historical review. Brain Res 18, 197-218.

[32] Serot JM, Béné MC, Foliguet B, Faure GC (2000) Morphological alterations of the choroid plexus in late-onset Alzheimer's disease. Acta Neuropathol 99, 105-108.

[33] Serot JM, Béné MC, Foliguet B, Faure GC (2010) Monocyte-derived IL-10-secreting dendritic cells in choroid plexus epithelium. J Neuroimmunol 105, 115-119.

[34] Wolfram-Gabel R, Maillot C, Koritké JG, Laude M (1987) The vascularization of the human tela choroidea of the lateral ventricle. Acta Anat 128, 301-321.

[35] Faraci FM, Mayhan WG, Heistad DD (1989) Effect of serotonin on blood flow to the choroid plexus. Brain Res 478 , 121-126.

[36] Wostyn P, Audenaert K, De Deyn PP (2011) Choroidal proteins involved in cerebrospinal fluid production may be 
potential drug targets for Alzheimer's disease therapy. Perspect Medicin Chem 5, 11-17.

[37] Boassa D, Stamer WD, Yool AJ (2006) Ion channel function of aquaporin-1 natively expressed in choroid plexus. $J$ Neurosci 26, 7811-7819.

[38] Zheng W (1996) Choroid plexus and metal toxicity. In: Toxicology of metals, Chang LW, ed., CRC Lewis Publishers, London, pp. 609-626.

[39] Aldred AR, Brack CM, Schreiber G (1995) The cerebral expression of plasma protein gene in different species. Comp Biochem Physiol 111B, 1-15.

[40] Ingenbleek Y, Young V (1994) Transthyretin (prealbumin) in health and disease: Nutritional implications. Апnи Rev Nutr 14, 495-533.

[41] Segal MB (2001) Transport of nutrients across the choroid plexus. Microsc Res Tech 52, 38-48.

[42] Spector R (2009) Nutrient transport systems in brain: 40 years of progress. J Neurochem 111, 315-320

[43] Strazielle N, Khuth ST, Ghersi-Egea JF (2004) Detoxification systems, passive and specific transport for drugs at the blood-CSF barrier in normal and pathological situations. Adv Drug Deliv Rev 56, 1717-1740.

[44] Crossgrove JS, Li GJ, Zheng W (2005) The choroid plexus removes beta-amyloid from brain cerebrospinal fluid. Exp Biol Med 230, 771-776.

[45] Thanos CG, Bintz B, Emerich DF (2010) Microencapsulated choroid plexus epithelial cell transplants for repair of the brain. Adv Exp Med Biol 670, 80-91.

[46] Serot JM, Foliguet B, Béné MC, Faure GC (2001) Choroid plexus and ageing in rats: A morphometric and ultrastructural study. Eur J Neurosci 14, 794-798.

[47] Wen GY, Wisniewski HM, Kascsak RJ (1999) Biondi ring tangles in the choroid plexus of Alzheimer's disease and normal aging brains: A quantitative study. Brain Res $\mathbf{8 3 2}$, 40-46.

[48] Shuangshoti S, Netsky MG (1970) Human choroid plexus: Morphologic and histochemical alterations with age. Am J Anat 128, 73-96.

[49] Modic MT, Weinstein MA, Rothner AD, Erenberg G, Duchesneau PM, Kaufman B (1980) Calcification of the choroid plexus visualized by computed tomography. Radiology $\mathbf{1 3 5}$, 369-372.

[50] Kvitnitskaia-Ryzhova TI, Shkapenko AL (1992) A comparative ultracytochemical and biochemical study of the ATPases of the choroid plexus in aging. Tsitologiia 34, 81-87.

[51] Ferrante F, Amenta F (1987) Enzyme histochemistry of the choroid plexus in old rats. Mech Ageing Dev 41, 65-72.

[52] Masseguin C, LePanse S, Corman B, Verbavatz JM, Gabrion J (2005) Aging affects choroidal proteins involved in CSF production in Sprague-Dawley rats. Neurobiol Aging 26, 917-927.

[53] Emerich DF, Schneider P, Bintz B, Hudak J, Thanos CG (2007) Aging reduces the neuroprotective capacity, VEGF secretion, and metabolic activity of rat choroid plexus epithelial cells. Cell Transplant 16, 697-705.

[54] Preston JE (2001) Ageing choroid plexus-cerebrospinal fluid system. Microsc Res Tech 52, 31-37.

[55] Chen RL, Kassem NA, Redzic ZB, Chen CP, Segal MB, Preston JE (2009) Age-related changes in choroid plexus and blood-cerebrospinal fluid barrier function in the sheep. Exp Gerontol 44, 289-296.

[56] May C, Kaye JA, Atack JR, Schapiro MB, Friedland RP, Rapoport SI (1990) Cerebrospinal fluid production is reduced in healthy aging. Neurology $\mathbf{4 0}, 500-503$.
[57] Sakka L, Coll G, Chazal J (2011) Anatomy and physiology of cerebrospinal fluid. Eur Ann Otorhinolaryngol Head Neck Dis 128, 309-316.

[58] Redzic ZB, Preston JE, Duncan JA, Chodobski A, Szmydynger-Chodobska J (2005) The choroid plexuscerebrospinal fluid system: From development to aging. Curr Top Dev Biol 71, 1-52.

[59] Silverberg GD, Mayo M, Saul T, Rubenstein E, McGuire D (2003) Alzheimer's disease, normal-pressure hydrocephalus, and senescent changes in CSF circulatory physiology: A hypothesis. Lancet Neurol 2, 506-511.

[60] Courchesne E, Chisum HJ, Townsend J, Cowles A, Covington J, Egaas B, Harwood M, Hinds S, Press GA (2000) Normal brain development and aging: Quantitative analysis at in vivo MR imaging in healthy volunteers. Radiology $\mathbf{2 1 6}$, 672-682.

[61] Johanson CE, Duncan JA 3rd, Klinge PM, Brinker T, Stopa EG, Silverberg GD (2008) Multiplicity of cerebrospinal fluid functions: New challenges in health and disease. Cerebrospinal Fluid Res $\mathbf{5}, 10$.

[62] Reiber H (2001) Dynamics of brain-derived proteins in cerebrospinal fluid. Clin Chim Acta 310, 173-186.

[63] Serot JM, Christmann D, Dubost T, Couturier M (1997) Cerebrospinal fluid transthyretin: Aging and late onset Alzheimer's disease. J Neurol Neurosurg Psychiatry 63, 506-508.

[64] Lanz TA, Hosley JD, Adams WJ, Merchant KM (2004) Studies of Abeta pharmacodynamics in the brain, cerebrospinal fluid, and plasma in young (plaque-free) Tg2576 mice using the gamma-secretase inhibitor N2-[(2S)2-(3,5-difluorophenyl)-2-hydroxyethanoyl]-N1-[(7S)-5methyl-6-oxo-6,7-dihydro-5H-dibenzo[b,d]azepin-7-yl]L-alaninamide (LY-411575). J Pharmacol Exp Ther 309, 49-55.

[65] Serot JM, Peltier J, Fichten A, Ledeme N, Bourgeois AM, Jouanny $\mathrm{P}$, Toussaint $\mathrm{P}$, Legars $\mathrm{D}$, Godefroy $\mathrm{O}$, Mazière JC (2011) Reduced CSF turnover and decreased ventricular A $\beta 42$ levels are related. BMC Neurosci 12, 42.

[66] Oresković D, Klarica M (2010) The formation of cerebrospinal fluid: Nearly a hundred years of interpretations and misinterpretations. Brain Res Rev 64, 241-262.

[67] Oshio K, Watanabe H, Song Y, Verkman AS, Manley GT (2005) Reduced cerebrospinal fluid production and intracranial pressure in mice lacking choroid plexus water channel aquaporin-1. FASEB J 19, 76-78.

[68] Oshio K, Song Y, Verkman AS, Manley GT (2003) Aquaporin-1 deletion reduces osmotic water permeability and cerebrospinal fluid production. Acta Neurochir Suppl 86, 525-528

[69] Strozyk D, Blennow K, White LR, Launer LJ (2003) CSF Abeta 42 levels correlate with amyloid-neuropathology in a population-based autopsy study. Neurology 60, 652656.

[70] Fagan AM, Mintun MA, Mach RH, Lee SY, Dence CS, Shah AR, LaRossa GN, Spinner ML, Klunk WE, Mathis CA, DeKosky ST, Morris JC, Holtzman DM (2006) Inverse relation between in vivo amyloid imaging load and cerebrospinal fluid Abeta42 in humans. Ann Neurol 59, 512-519.

[71] Tapiola T, Alafuzoff I, Herukka SK, Parkkinen L, Hartikainen P, Soininen H, Pirttilä T (2009) Cerebrospinal fluid beta-amyloid 42 and tau proteins as biomarkers of Alzheimer-type pathologic changes in the brain. Arch Neurol 66, 382-389.

[72] Seppälä TT, Koivisto AM, Hartikainen P, Helisalmi S, Soininen H, Herukka SK (2011) Longitudinal changes of CSF 
biomarkers in Alzheimer's disease. J Alzheimers Dis 25, 583-594.

[73] Stomrud E, Hansson O, Zetterberg H, Blennow K, Minthon L, Londos E (2010) Correlation of longitudinal cerebrospinal fluid biomarkers with cognitive decline in healthy older adults. Arch Neurol 67, 217-223.

[74] Kaiser E, Schoenknecht P, Kassner S, Hildebrandt W, Kinscherf R, Schroeder J (2010) Cerebrospinal fluid concentrations of functionally important amino acids and metabolic compounds in patients with mild cognitive impairment and Alzheimer's disease. Neurodegener Dis 7, 251-259.

[75] Shuvaev VV, Laffont I, Serot JM, Fujii J, Taniguchi N, Siest $\mathrm{G}$ (2001) Increased protein glycation in cerebrospinal fluid of Alzheimer's disease. Neurobiol Aging 22, 397-402.

[76] Rahmadi A, Steiner N, Münch G (2011) Advanced glycation endproducts as gerontotoxins and biomarkers for carbonylbased degenerative processes in Alzheimer's disease. Clin Chem Lab Med 49, 385-391.

[77] Kester MI, Scheffer PG, Koel-Simmelink MJ, Twaalfhoven $\mathrm{H}$, Verwey NA, Veerhuis R, Twisk JW, Bouwman FH, Blankenstein MA, Scheltens P, Teunissen C, van der Flier WM (2011) Serial CSF sampling in Alzheimer's disease: Specific versus non-specific markers. Neurobiol Aging, july 6 [epub ahead of print].

[78] Silverberg GD, Heit G, Huhn S, Jaffe RA, Chang SD, Bronte-Stewart H, Rubenstein E, Possin K, Saul TA (2001) The cerebrospinal fluid production rate is reduced in dementia of the Alzheimer's type. Neurology 57, 1763-1766.

[79] Silverberg G, Mayo M, Saul T, Fellmann J, McGuire D (2006) Elevated cerebrospinal fluid pressure in patients with Alzheimer's disease. Cerebrospinal Fluid Res 3, 7

[80] El Sankari S, Gondry-Jouet C, Fichten A, Godefroy O, Serot JM, Deramond H, Meyer ME, Balédent O (2011) Cerebrospinal fluid and blood flow in mild cognitive impairment and Alzheimer's disease: A differential diagnosis from idiopathic normal pressure hydrocephalus. Fluids Barriers CNS $\mathbf{8}, 12$

[81] Del Bigio MR, Cardoso ER, Halliday WC (1997) Neuropathological changes in chronic adult hydrocephalus: Cortical biopsies and autopsy findings. Can J Neurol Sci 24, 121-126.

[82] Di Rocco C, Di Trapani G, Maira G, Bentivoglio M, Macchi G, Rossi GF (1977) Anatomo-clinical correlations in normotensive hydrocephalus. Reports on three cases. J Neurol Sci 33, 437-452.

[83] Bech RA, Juhler M, Waldemar G, Klinken L, Gjerris F (1997) Frontal brain and leptomeningeal biopsy specimens correlated with cerebrospinal fluid outflow resistance and B-wave activity in patients suspected of normal-pressure hydrocephalus. Neurosurgery 40, 497-502.

[84] Savolainen S, Paljärvi L, Vapalahti M (1999) Prevalence of Alzheimer's disease in patients investigated for presumed normal pressure hydrocephalus: A clinical and neuropathological study. Acta Neurochir 141, 849-853.

[85] Golomb J, Wisoff J, Miller DC, Boksay I, Kluger A, Weiner H, Salton J, Graves W (2000) Alzheimer's disease comorbidity in normal pressure hydrocephalus: Prevalence and shunt response. J Neurol Neurosurg Psychiatry 68, 778-781.

[86] Leinonen V, Koivisto AM, Savolainen S, Rummukainen. J, Tamminen JN, Tillgren T, Vainikka S, Pyykkö OT, Mölsä J, Fraunberg M, Pirttilä T, Jääskeläinen JE, Soininen H, Rinne J, Alafuzoff I (2010) Amyloid and tau proteins in cortical brain biopsy and Alzheimer's disease. Ann Neurol 68, 446453.
[87] Agren-Wilsson A, Lekman A, Sjöberg W, Rosengren L, Blennow K, Bergenheim AT, Malm J (2007) CSF biomarkers in the evaluation of idiopathic normal pressure hydrocephalus. Acta Neurol Scand 116, 333-339.

[88] Kapaki EN, Paraskevas GP, Tzerakis NG, Sfagos C, Seretis A, Kararizou E, Vassilopoulos D (2007) Cerebrospinal fluid tau, phospho-tau181 and beta-amyloid1-42 in idiopathic normal pressure hydrocephalus: A discrimination from Alzheimer's disease. Eur J Neurol 14, 168-173.

[89] Wostyn P, Van Dam D, Audenaert K, De Deyn PP (2011) Increased Cerebrospinal Fluid Production as a Possible Mechanism Underlying Caffeine's Protective Effect against Alzheimer's Disease. Int J Alzheimers Dis 2011, 617420.

[90] Han ME, Kim HJ, Lee YS, Kim DH, Choi JT, Pan CS, Yoon S, Baek SY, Kim BS, Kim JB, Oh SO (2009) Regulation of cerebrospinal fluid production by caffeine consumption. BMC Neurosci 10, 110

[91] Arendash GW, Schleif W, Rezai-Zadeh K, Jackson EK, Zacharia LC, Cracchiolo JR, Shippy D, Tan J (2006) Caffeine protects Alzheimer's mice against cognitive impairment and reduces brain beta-amyloid production. Neuroscience 142, 941-952.

[92] Wisniewski T, Castano E, Ghiso J, Frangione B (1993) Cerebrospinal fluid inhibits Alzheimer beta-amyloid fibril formation in vitro. Ann Neurol 34, 631-633.

[93] Hansson SF, Andréasson U, Wall M, Skoog I, Andreasen $\mathrm{N}$, Wallin A, Zetterberg H, Blennow K (2009) Reduced levels of amyloid-beta-binding proteins in cerebrospinal fluid from Alzheimer's disease patients. J Alzheimers Dis 16, 389-397.

[94] Tohgi H, Abe T, Nakanishi M, Hamato F, Sasaki K, Takahashi S (1994) Concentrations of alpha-tocopherol and its quinone derivative in cerebrospinal fluid from patients with vascular dementia of the Binswanger type and Alzheimer type dementia. Neurosci Lett 174, 73-76.

[95] Bowman GL, Dodge H, Frei B, Calabrese C, Oken BS, Kaye JA, Quinn JF (2009) Ascorbic acid and rates of cognitive decline in Alzheimer's disease. J Alzheimers Dis 16, 93-98.

[96] Serot JM, Christmann D, Dubost T, Béne MC, Faure GC (2001) CSF-folate levels are decreased in late-onset AD patients. J Neural Transm 108, 93-99.

[97] Ikeda T, Furukawa Y, Mashimoto S, Takahashi K, Yamada M (1990) Vitamin B12 levels in serum and cerebrospinal fluid of people with Alzheimer's disease. Acta Psychiatr Scand 82, 327-329.

[98] Selley ML, Close DR, Stern SE (2002) The effect of increased concentrations of homocysteine on the concentration of (E)-4-hydroxy-2-nonenal in the plasma and cerebrospinal fluid of patients with Alzheimer's disease. Neurobiol Aging 23, 383-388.

[99] Ho PI, Ashline D, Dhitavat S, Ortiz D, Collins SC, Shea TB, Rogers E (2003) Folate deprivation induces neurodegeneration: Roles of oxidative stress and increased homocysteine. Neurobiol Dis 14, 32-42.

[100] Miranda VH, Outeiro TF (2010) The sour side of neurodegenerative disorders: The effects of protein glycation. J Pathol 221, 13-25.

[101] Jellinger K (1976) Neuropathological aspects of dementias resulting from abnormal blood and cerebrospinal fluid dynamics. Acta Neurol Belg 76, 83-102.

[102] Wen GY, Wisniewski HM, Kascsak RJ (1999) Biondi ring tangles in the choroid plexus of Alzheimer's disease and normal aging brains: A quantitative study. Brain Res 832, 40-46. 
[103] Perez-Gracia E, Blanco R, Carmona M, Carro E, Ferrer I (2009) Oxidative stress damage and oxidative stress responses in the choroid plexus in Alzheimer's disease. Acta Neuropathol 118, 497-504.

[104] Dorta-Contreras AJ, Barshatzky M, Noris-García E Serrano-Sánchez T (2000) Transthyretin levels in serum and cerebrospinal fluid sustain the nutrio-viral hypothesis of the Cuban epidemic neuropathy. Rev Neurol 31, 801804

[105] Del Bigio MR (1993) Neuropathological changes caused by hydrocephalus. Acta Neuropathol 85, 573-585.

[106] Dohrmann GJ (1971) The choroid plexus in experimental hydrocephalus. A light and electron microscopic study in normal, hydrocephalic, and shunted hydrocephalic dogs. J Neurosurg 34, 56-69.
[107] Wostyn P, van Dam D, Audenaert K, de Deyn PP (2011) Genes involved in cerebrospinal fluid production as candidate genes for late-onset Alzheimer's disease: A hypothesis J Neurogenet 25, 195-200.

[108] Choi SH, Leight SN, Lee VM, Li T, Wong PC, Johnson JA Saraiva MJ, Sisodia SS (2007) Accelerated Abeta deposition in APPswe/PS1deltaE9 mice with hemizygous deletions of TTR (transthyretin). J Neurosci 27, 7006-7010.

[109] Natunen T, Helisalmi S, Vepsäläinen S, Sarajärvi T, Antikainen L, Mäkinen P, Herukka SK, Koivisto AM, Haapasalo A, Soininen H, Hiltunen M (2012) Genetic analysis of genes involved in amyloid- $\beta$ degradation and clearance in Alzheimer's disease. J Alzheimers Dis 28, 553-559. 